Título artículo / Títol article: Sexual Compulsivity Scale: Adaptation and Validation in the Spanish Population

Autores / Autors

Ballester Arnal, Rafael ; Gómez Martínez, Sandra ; Gil Llario, María Dolores ; Salmerón Sánchez, Pedro

Revista:

Journal of sex \& marital therapy (2013) vol. 39, no 6

Versión / Versió:

Postprint del autor

Cita bibliográfica / Cita

BALLESTER-ARNAL, Rafael, et al. Sexual bibliogràfica (ISO 690):

Compulsivity Scale: Adaptation and Validation in the Spanish Population. Journal of sex \& marital therapy, 2013, vol. 39, no 6, p. 526-540.

url Repositori UJI:

http://hdl.handle.net/10234/92261 


\title{
Sexual Compulsivity Scale: Adaptation and Validation in Spanish Population
}

\author{
RAFAEL BALLESTER ARNAL and SANDRA GÓMEZ MARTÍNEZ \\ Jaume I University, Basic and Clinical Psychology and Psychobiology, Castellón, Spain \\ M. DOLORES GIL LLARIO \\ University of Valencia, General Study, Developmental and Education Psychology, \\ Valencia, Spain \\ PEDRO SALMERÓN SÁNCHEZ \\ Jaume I University, Basic and Clinical Psychology and Psychobiology, Castellón, Spain
}

\begin{abstract}
Sexual compulsivity has been studied in relation to high-risk behavior for sexually transmitted infections. The aim of this study was the adaptation and validation of the Sexual Compulsivity Scale to a sample of Spanish young people. This scale was applied to 1,196 (891 female, 305 male) Spanish college students. The results of principal components factor analysis using a varimax rotation indicated a two-factor solution; similar results were obtained in another study. The reliability of the Sexual Compulsivity Scale was found to be high. Moreover, the scale showed good temporal stability. External correlates were examined through Pearson correlations between the Sexual Compulsivity Scale and other constructs related with HIV prevention. The authors' results suggest that the Sexual Compulsivity Scale is an appropriate measure for assessing sexual compulsivity, showing adequate psychometric properties in the Spanish population.
\end{abstract}

According to Kalichman and Cain (2004), sexual compulsivity is a propensity
26 to experience sexual disinhibition and under controlled sexual impulses and
behaviors as self-identified by individuals. It can be considered a heteroge-
28 neous psychological construct that includes a concern for and increase-in
intensity and frequency-in sexual fantasies, behavior patterns, and de-
30 sires that can lead to problems in daily life as (Kalichman \& Cain, 2004;

Address correspondence to Rafael Ballester Arnal, Jaume I University, Basic and Clinical Psychology and Psychobiology, Castellón, Spain. E-mail: rballest@uji.es
Q2 
Bancroft, 2008). low self-esteem, anxiety, loneliness, impaired social skills, occupational difficulties, guilt, and shame (Black, Kehrberg, Flumerfelt, \& Schlosser, 1997; Kalichman \& Rompa, 1995). Furthermore, researchers have defined various symptoms related to sexual compulsivity, such as excessive pornography use, sex with multiple anonymous partners, an excessive use of Internet for sexual purposes, and increased anxiety when not engaged in sexual behavior (Parsons et al., 2008; Parsons, Severino, Grov, Bimbi, \& Morgenstern, 2007).

Sexual compulsivity has also health implications because of increased risk of HIV infection and other sexually transmitted infections (Dodge, Reece, Cole, \& Sandfort, 2004; Kalichman \& Rompa, 1995; McCoul \& Haslam, 2001). Benotsch, Kalichman, and Kelly (1999), in a study carried out with HIVpositive self-identified gay and bisexual men, found that people who scored higher in sexual compulsivity reported more frequent receptive and totally unprotected anal and oral sex acts with more partners Q her researchers have found similar results (e.g., Grov, Parson, \& Bimbi, LOI0; Kalichman \& Rompa, 2001; Kelly, Bimbi, Nanin, Izienicki, \& Parsons, 2009).

As a result of this growing interest in the relation between sexual compulsivity and high-risk behavior for HIV infection, some authors have proposed different questionnaires to evaluate sexual compulsivity (Table 1). Kalichman et al.'s (1994) study was the first attempt to assess sexual compulsivity specifically. They proposed the Sexual Compulsivity Scale (SCS) as a tool for studying underlying compulsive personality traits that may be associated with resistance to changing sexual behavior patterns despite exposure to messages and initiatives aimed at preventing HIV. We subsequently describe in detail the characteristics of this instrument.

After reviewing the literature, we decided to translate and validate the SCS because it is a short questionnaire with good psychometric properties and has been used in different studies to analyze associations between personality traits and behavior change for HIV. In this sense, the scale has been shown to be useful in the prediction of unprotected sex (Grov et al., 2010). It has also been used in different types of populations, including college students (Gullete \& Lyons, 2005).

This instrument consists of 10 statements largely based on a 12-step self-help manual (CompCare, 1987) for people seeking recovery from sexual addiction. The pilot study of the scale (Kalichman et al., 1994) was conducted with a sample of sexually active men who considered themselves homosexuals $(n=160)$. The results showed high levels of reliability $(\alpha=$ .89). Later, Kalichman and Rompa (1995) used the scale in two different samples: (a) one of gay men $(n=296)$ and (b) one of African American men $(n=60)$ and African American women $(n=98)$ from inner-city areas and low-income groups. The scale showed high levels of internal consistency ( $\alpha=.86$ for gay men and $\alpha=.87$ for African American men and women). In 


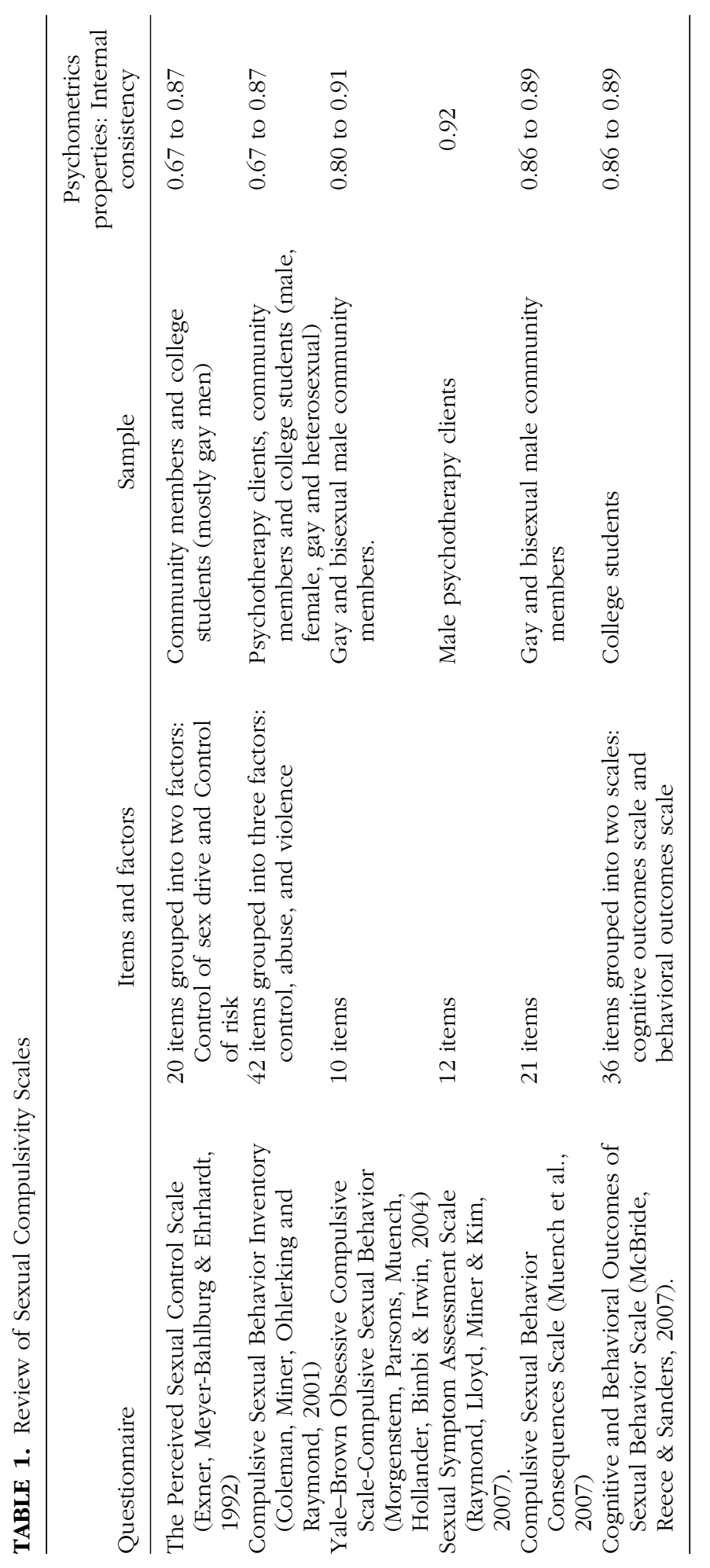


both samples, there are significant correlations between sexual compulsivity, high-risk sexual behavior, and drug use before sex.

Although this scale has been used to evaluate sexual compulsivity, especially among individuals belonging to groups deemed at high risk or HIVpositive individuals, the few studies conducted in college students suggest that higher scores in sexual compulsivity are associated with a higher number of unprotected sexual encounters (Dodge et al., 2004; Gullete \& Lions, 2005). To design optimal prevention campaigns, it is necessary to identify the characteristics of those most likely to engage in high-risk behavior (McBride, Reece, \& Sanders, 2008).

The aim of our study was therefore to translate, adapt, and validate the SCS of Kalichman et al. (1994) in a Spanish population that has been little studied-young people-represented here by a sample of college students. Although college students have not been identified as a risk population theoretically $\rho$ eral studies in Spain and in other countries have emphasized the high presance of risky sexual behavior in this population (Ballester, Gil, Giménez, \& Ruiz, 2009; McBride et al., 2008; Rolison, 2002).

\section{Participants}

The questionnaire was responded by 1,196 Spanish college students of the Jaume I University and the University of Valencia, ranging between 18 and 26 years of age. Most participants were women (74.5\%) who were 18-20 years old $(60.9 \% ; M=20.22, S D=2.11)$, heterosexual $(95.5 \%)$ and nonpracticing Catholics $(44.7 \%)$ or atheists $(43.9 \%)$.

\section{Measures and Instruments}

Participants responded individually to the SCS. To assess convergent and divergent validity, the participants also answered the Sexual Sensation Seeking Scale (Kalichman et al., 1994), the Spanish version of the Beck Depression Inventory (Beck, Rush, Shaw, \& Emery, 1979 [translated by Sanz \& Vázquez, 1998]) and The Brief Version of the Fear of Negative Evaluation Scale (Leary, 1983). Last, they responded to the Cuestionario de Prevención del Sida ("AIDS Q Oention Questionnaire"; Ballester, Gil, Guirado, \& Bravo, 2004), which wabuveloped in Spanish.

We subsequently explain these questionnaires:

- SCS (Kalichman et al., 1994): This scale consists of 10 Likert-type items that assess sexual compulsivity, measured on a scale ranging from 1 (not at all like me) to 4 (very much like me), with a total score between 10 and 40 . The internal consistency of the instrument applied to a sample of college 
students was .76 for men and .81 for women (Reece, Plate, \& Daughtry, 2001).

- Sexual Sensation Seeking Scale (Kalichman et al., 1994): This scale is designed to measure "the propensity to attain optimal levels of sexual excitement and to engage in novel sexual experiences." It consists of 9 Likert-type items measured on a 4-point scale ranging from 1 (not at all like me) to 4 (very much like me), with a total score range between 9 and 36. The instrument has shown an internal consistency of .81 in various samples, such as gay men (Kalichman \& Rompa, 1995) and college students (Gray \& Wilson, 2007).

- Beck Depression Inventory in its Spanish Version (Sanz \& Vázquez, 1998): This scale is a 21-question multiple-choice self-report inventory that reflects cognitive, affective, behavioral, and somatic symptoms of depression in relation to the 7 previous days. The items are answered according to a 4-point scale denoting different levels of severity and intensity. The Spanish version has shown good internal consistency in a sample of college students (.83).

- Cuestionario de Prevención del Sida (CPS; "AIDS Prevention Questionnaire"): This questionnaire, by Ballester et al. (2004), consists of 65 items referring to HIV infection, transmission routes, preventive methods and behaviors, antibodies test, and attitude toward HIV-positive people. Internal consistency of the scale in a sample of college students was properly analyzed ( $\alpha=.70$; Ballester, Gil, \& Giménez, 2007).

We present the SCS validated in this work for the Spanish population in Appendix A.

\section{Procedure}

We informed 1,196 participants of the purpose of the study. The research team told participants that they would be assessed on several sexual behaviors in young people. Then, they completed the SCS voluntarily, anonymously, and confidentially in one sitting during class time thanks to the collaboration of lecturers in different degree courses. In addition, the first 300 tested students also responded to questionnaires described earlier. After a week, 100 randomly selected participants answered the SCS a second time. Our research group translated the Sexual Sensation Seeking Scale (Kalichman et al., 1994) and the SCS (Kalichman et al., 1994) according to the established international strategies (Hambleton, Merenda, \& Spielberger, 2005).

\section{Statistical Analysis}

We used SPSS to perform all of our analyses. We used a principal component factor analysis using varimax rotation to ascertain the factorial structure 
of the questionnaire. In addition, we performed a descriptive analysis of items and calculated internal consistency using Cronbach's alpha coefficient. We examined convergent validity through Pearson correlations between the SCS and other constructs related to HIV prevention (total score of Sexual Sensation Seeking Scale, Beck Depression Inventory, and an item from the Cuestionario de Prevención del Sida that requested information about the number of sexual partners). Selection was carried out according to the relationship between these elements and sexual compulsivity in the literature (Benostch et al., 1999; Gullete \& Lions, 2005; Kalichman, Greenberg, \& Abel, 1997; Kalichman \& Rompa, 1995, 2001; Raymond, Coleman, \& Miner, 2003). We calculated test-retest reliability through Pearson's correlation coefficient.

\section{Factorial Structure of the SCS}

We obtained an index of .896 in the Kaiser-Meyer-Olkin test, and Bartlett test of sphericity results of $\chi^{2}(45)=3551.851, p<.001$. We therefore concluded that factor analysis was appropriate.

We performed a factor analysis by extracting the principal components with varimax rotation, revealing a two-factor solution with eigenvalues higher than one, which explained $52.74 \%$ of total variance (Table 2). The first factor, with an eigenvalue of 4.237 , accounted for $42.37 \%$ of the variance and included five items $(1,2,3,4$, and 10) that represented an "interference of sexual behavior" whereby sexual compulsivity caused interpersonal relationship problems and social maladjustment. The second one, with an eigenvalue of 1.037 , accounted for $10.37 \%$ of variance and represented a "failure to control sexual impulses" and entailed personal discomfort associated with sexual compulsivity (Items 5, 6, 7, 8, and 9).

\section{Descriptive Analysis of Items}

In the total sample, the ratings given to the items ranged between 1.141 and 1.623 Table 3 shows that Items 5 and 6 had the highest scores and Items 2 and $4 \mathrm{had}$ the lowest. In the men sample, the scores ranged between 1.24 and 1.84. Items 6 and 9 scored higher, while Items 2 and 4 scored lower. In the female sample, Items 5 and 6 were rated higher. In both samples, Items 2 and 4 were rated lower.

\section{Internal Consistency}

To analyze internal consistency, we calculated Cronbach's alpha coefficient for total scale $(\alpha=.837)$. Correlations of individual items with corrected total 
TABLE 2. Results of a Principal Components Analysis

\begin{tabular}{|c|c|c|c|}
\hline Subscale and items & Factor 1 & Factor 2 & Communalities \\
\hline \multicolumn{4}{|l|}{ Interference of sexual behavior } \\
\hline $\begin{array}{l}\text { 1. My sexual appetite has gotten in the way of } \\
\text { my relationships. }\end{array}$ & 0.690 & 0.221 & 0.525 \\
\hline $\begin{array}{l}\text { 2. My sexual thoughts and behaviors are } \\
\text { causing problems in my life. }\end{array}$ & 0.751 & 0.128 & 0.581 \\
\hline $\begin{array}{l}\text { 3. My desires to have sex have disrupted my } \\
\text { daily life. }\end{array}$ & 0.674 & 0.315 & 0.553 \\
\hline $\begin{array}{l}\text { 4. I sometimes fail to meet my commitments } \\
\text { and responsibilities because of my sexual } \\
\text { behaviors. }\end{array}$ & 0.603 & 0.174 & 0.394 \\
\hline $\begin{array}{l}\text { 10. It has been difficult for me to find sex } \\
\text { partners who desire having sex as much as I } \\
\text { want to. }\end{array}$ & 0.547 & 0.223 & 0.349 \\
\hline \multicolumn{4}{|l|}{ Failure to control sexual impulses } \\
\hline $\begin{array}{l}\text { 5. I sometimes get so horny I could lose } \\
\text { control. }\end{array}$ & 0.118 & 0.765 & 0.600 \\
\hline $\begin{array}{l}\text { 6. I find myself thinking about sex while at } \\
\text { work. }\end{array}$ & 0.181 & 0.708 & 0.534 \\
\hline $\begin{array}{l}\text { 7. I feel that my sexual thoughts and feeling } \\
\text { are stronger than I am. }\end{array}$ & 0.265 & 0.773 & 0.669 \\
\hline $\begin{array}{l}\text { 8. I have to struggle to control my sexual } \\
\text { thoughts and behavior. }\end{array}$ & 0.399 & 0.682 & 0.624 \\
\hline 9. I think about sex more than I would like to. & 0.413 & 0.524 & 0.445 \\
\hline
\end{tabular}

score of the SCS, that is, the total score regardless of the item concerned, ranged between 0.434 and 0.675 (see Table 3). In the interference subscale, correlations ranged between 0.402 and 0.549 . In the failure to control sexual impulses subscale, correlations ranged between 0.505 and 0.661 .

\section{Construct Validity}

To examine convergent validity, we used data from 300 participants who answered the SCS, the Sexual Sensation Seeking Scale (Kalichman \& Rompa, 1995), the Beck Depression Inventory (Beck et al., 1979), and the Cuestionario de Prevención del Sida (Ballester et al., 2004). Of total participants, 18 were removed because of a failure to respond to all items in the questionnaires. Therefore, we used data from 282 participants.

8 Convergent Validity

We calculated convergent validity using Pearson's correlation coefficient between the SCS, the Sexual Sensation Seeking Scale (Kalichman \& Rompa, 1995), the Beck Depression Inventory (Beck et al., 1979) and the number of sexual partners, an item included in CPS (Ballester et al., 2004). Sexual 


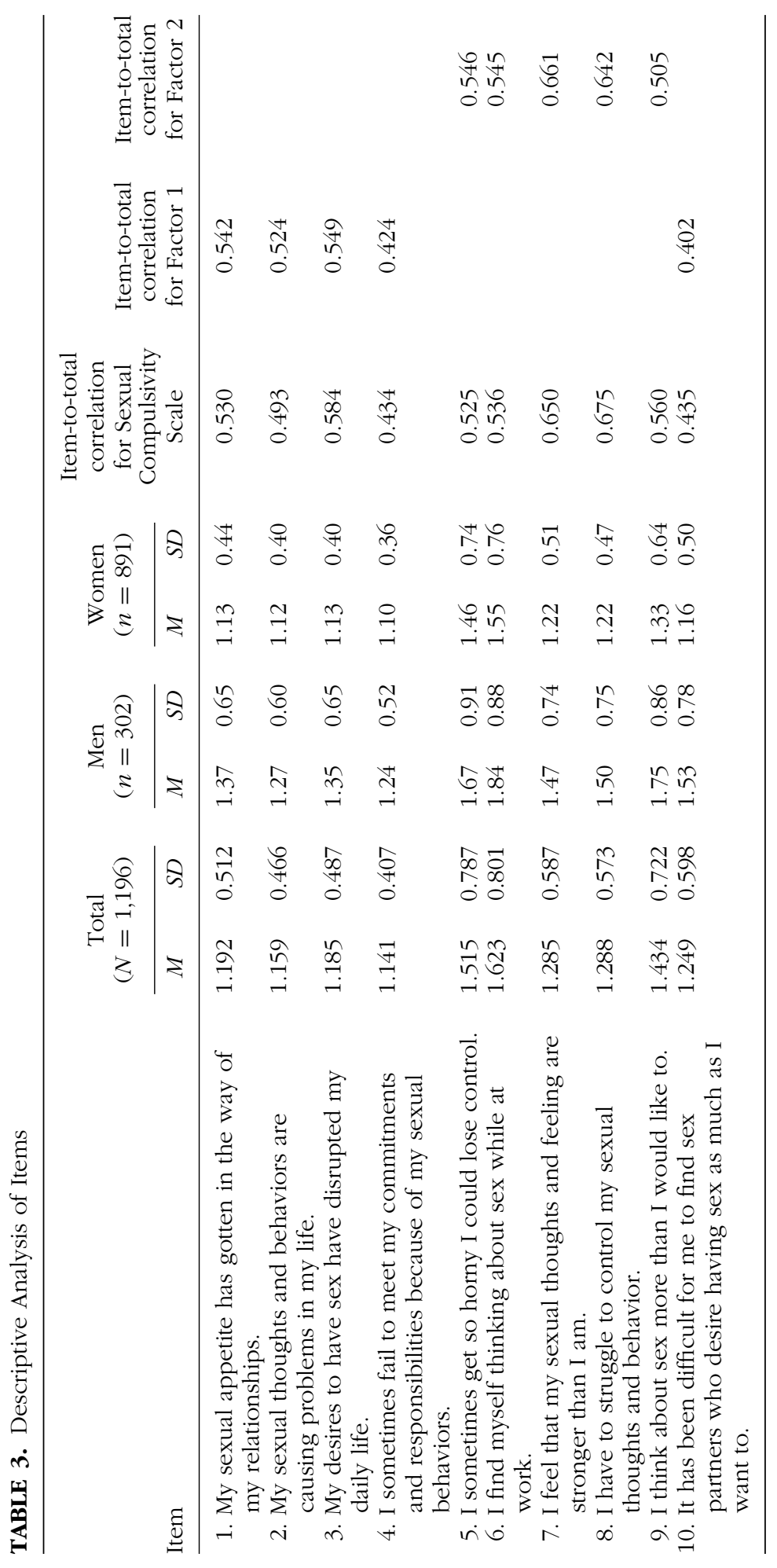


compulsivity rarely-if ever-stands alone. There are often comorbid issues in sexual compulsivity such as sexual dysfunction, physiological issues, other substances or addictions, depression and anxiety, or posttraumatic stress disorder (Delmonico \& Griffin, 2011). Furthermore, there are several studies in literature that have concluded that sexual compulsivity and sexual sensation seeking had a significant contribution to realization of sexual risk behaviors (Beck, Thombs, Mahoney, \& Fingar, 1995; Reece et al., 2001). As expected, our results show that the scale had a significant positive correlation with Sexual Sensation Seeking Scale $(r=0.444, p<.000)$, Beck Depression Inventory $(r=0.161, p<.007)$ and with the number of sexual partners, an item of Cuestionario de Prevención del Sida $(r=.203, p<.001)$.

\section{Test-Retest Reliability}

Of the total sample $(N=1,196), 100$ young people answered the SCS a week later, but 9 of these were excluded because of their failure to answer any of the items. We therefore analyzed test-retest reliability with 91 participants by calculating Pearson's correlation coefficient. There were significant correlations in both total scale and subscales between the two occasions of administration. Thus, correlation between total scale score in each pass was $0.725(p<.01)$.

In previous studies, Kalichman and Cain (2004) and McBride et al. (2008) found a two-factor solution for the SCS. Both called these factors in the same way: Factor 1 was called social disruptiveness and Factor 2 was called personal discomfort. However, some items (2, 5, 6, and 7) are grouped on opposite factors on these studies. In our study, there is also a twofactor solution, but we have named them differently. Factor 1 was labeled as interference of sexual behavior, while Factor 2 was called "failure to control sexual impulses When analyzing the two factors obtained, it is apparent that they both reflect variations in factor loadings of individual items compared to those obtained in the study by McBride et al. (2008), which was also conducted with a sample of young people. However, our results are similar to those obtained by Kalichman and Cain (2004) in a sample of men and women receiving services from sexually transmitted infection clinic with different ages to those in our study. There is a difference in factor loading of Item 10, "It has been difficult for me to find sex partners who desire having sex as much as I want to." The item belongs to the personal discomfort factor in the study of Kalichman et al. (2004), while it belongs to the interference of sexual behavior factor in our sample. 
Relating to descriptive analysis of the items, the sample of the present study has the lowest scores of sexual compulsivity compared with other samples in other studies.

Because sexual compulsivity has been associated to risky sexual behaviors and increased sexual frequency, it is reasonable that means obtained in the college students sample were lower than those of other that assessed M/MSMW campus cruisers (Reece \& Dodge, 2004), people living with HIV (Denotsch, Kalichman, \& Pinkerton, 2001; Kalichman \& Rompa, 2001; Reece, 2003) or gay/bisexual male sex workers (Parson et al., 2001). In contrast, it is important to note that in all studies the mean score of sexual compulsivity is higher in men than in women; educational and social factors may possibly account for these differences.

In terms of reliability, SCS has shown good internal consistency in total scale $(\alpha=.837)$ and in subscales. (Internal consistency of the scale obtained in this study is slightly higher than that found by Dodge et al. (2004) among students aged 18 to 25 years old $(\alpha=.82$ ). However, our result is slightly lower than the pilot study of the scale undertaken by Kalichman et al. (1994) in which participants were sexually active men who considered themselves homosexual ( $\alpha=.89)$. It was also been slightly lower than the original study by Kalichman and Rompa (1995) of gay men $(\alpha=.86)$ and of primarily African American men and women in inner-city areas on low incomes ( $\alpha=$ .88). In any case, few differences are mere hundredths, that is, the results are virtually identical.

In relation to convergent validity, this study found significant relationships between SCS and another measures. As expected, the Sexual Sensation Seeking Scale, the number of sexual partners and the participation in risky behavior correlated positively and significantly with SCS. Our result is consistent with those obtained in previous studies, where it was concluded that the Sensation seeking and sexual compulsivity had a significant contribution to realization of risky sexual behaviors (Beck et al, 1995; Reece et al., 2001). In another study, age, sexual sensation seeking, and sexual compulsivity were shown as predictors of risk behaviors (Gullette \& Lyons, 2005). Referring to depression, our results show significant positive correlations between this variable and sexual compulsivity. This is also in line with the literature reviewed. Across studies, people with high scores on compulsivity have extremely high rates of psychological disorders, in particular depression, anxiety disorders and substance use disorders (Black et al., 1997; Raymond et al., 2003).

As for the scale's temporal stability, the results of this study show that it is high for the scale. That value is similar to previous studies (Kalichman \& Rompa, 1995). The results obtained suggest that the SCS built by Kalichman et al. (1994) and translated by our team for Spanish population, is an appropriate measure for evaluating sexual compulsivity related with 
HIV prevention in young people. The scale shows adequate psychometric properties.

Our study has some limitations that should be considered in future research, such as number of participants of each sex-there were many more women than men in this study- and sexual orientation-most of the individuals in this sample were heterosexual students.

It is highly desirable to complete the sample with more men and people with different sexual orientations. Furthermore, it would be interesting to use a clinical group of patients suffering from sexual compulsivity to compare their scores with those of the general population and thus to establish a cutoff point with greater clinical significance.

\section{REFERENCES}

Ballester, R., Gil, M. D., \& Giménez, C. (2007, June). El "Cuestionario de Prevención del Sida (CPS): Análisis de fiabilidad y validez [ENGLISH TRANSLATION] Congreso sobre el sida de la Sociedad Española Interdisciplinaria de Sida, Sebastián, España.

Ballester, R., Gil, M. D., Giménez, C., \& Ruiz, E. (2009). Actitudes y conductas sexuales de riesgo para la infección por VIH/Sida en jóvenes españole (ID) TLISH TRANSLATION]. Revista de Psicopatología y Psicología Clínica, 14, 181-191. de prevención del SIDA dirigido a estudiantes universitarios: Datos preliminaries [ENGLISH TRANSLATI@IV Congreso de la Asociación Española de Psicología Clinica y Psicopatologia. Sevilla, 25-27 marzo. p. 63.

Beck, A. T., Rush, A. J., Shaw, B. F., \& Emery, G. (1979). Cognitive therapy of depression. New York, NY: Guilford Press.

Beck, K. H., Thombs, D. L., Mahoney, C. A., \& Fingar, K. M. (1995). Social context and sensation seeking: Gender differences in college students drinking motivations. International Journal of Addiction, 30, 1101-1115.

Benotsch, E. G., Kalichman, S. C., \& Kelly, J. A. (1999). Sexual compulsivity and substance use in HIV seropositive men who have sex with men: Prevalence and predictors of high-risk behaviors. Addictive Behaviors, 24, 857-868.

Benotsch, E. G., Kalichman, S. C., \& Pinkerton, S. D. (2001). Sexual compulsivity in HIV-positive men and women: Prevalence, predictors, and consequences of high-risk behaviors. Sexual Addiction and Compulsivity, 8, 83-99.

Black, D. W., Kehrberg, L. L. D., Flumerfelt, D. L., \& Schlosser, S. S. (1997). Characteristics of 36 subjects reporting compulsive sexual behavior. American Journal of Psychiatry, 154, 243-249.

Coleman, E., Miner, M., Ohlerking, F., \& Raymond, N. (2001). Compulsive sexual behavior inventory: A preliminary study of reliability and validity. Journal of Sex \& Marital Therapy, 27, 325-332.

DImonico, D. L., \& Griffin, E. (2011). The challenge of treating compulsive sex. Retrieved from http://www.fullspectrumrecovery.com/fullspec/images/stories/ pdfs/Treating\%20compulsive\%20sex.pdf 
Dodge, B., Reece, M., Cole, S. L., \& Sandfort, T. G. M. (2004). Sexual compulsivity among heterosexual college students. Journal of Sex Research, 41, 343-350.

Gray, J., \& Wilson, M. (2007). A detailed analysis of the reliability and validity of the sensation seeking scale in a UK sample. Personality and Individual Differences, 42, 641-651.

Grov, C., Parsons, J. T., \& Bimbi, D. S. (2010). Sexual compulsivity and sexual risk in gay and bisexual men. Archives of Sex Behavior, 39, 940-949.

Gullette, D. L., \& Lyons, M. A. (2005). Sexual sensation seeking, compulsivity, and HIV risk behaviors in college students. Journal of Community Health Nursing, 22, 47-60.

Hambleton, R. K., Merenda, P. E., \& Spielberger, C. D. (2005). Adapting educational and psychological tests for cross-cultural assessment. London, England: Erlbaum.

Kalichman, S. C., \& Cain, D. (2004). The relationship between indicators of sexual compulsivity and high-risk sexual practices among men and women receiving services from a sexually transmitted infection clinic. Journal of Sex Research, 41, 235-241.

Kalichman, S. C., Greenberg, J., \& Abel, G. G. (1997). HIV-seropositive men who engage in high-risk sexual behavior: Psychological characteristics and implications for prevention. AIDS Care, 9, 441-450.

Kalichman, S. C., Johnson, J. R., Adair, V., Rompa, D., Multhauf, K., \& Kelly, J. A. (1994). Sexual sensation seeking: Scale and development and predicting AIDS-risk behavior among homosexually active men. Journal of Personality Assessment, 62, 385-397.

Kalichman, S. C., \& Rompa, D. (1995). Sexual sensation seeking and sexual compulsivity scales: Reliability, validity, and predicting HIV risk behavior. Journal of Personality Assessment, 65, 586-601.

Kalichman, S. C., \& Rompa, D. (2001). The sexual compulsivity scale: Further development and use with HIV-positive persons. Journal of Personality Assessment, 76, 379-395.

Kelly, B. C., Bimbi, D. S., Nanin, J. E., Izienicki, H., \& Parsons, J. T. (2009). Sexual compulsivity and sexual Behaviors among gay and bisexual men and lesbian and bisexual women. Journal of Sex Research, 46, 301-308.

McBride, K. R., Reece, M., \& Sanders, S. A. (2007). Predicting negative outcomes of sexuality using the Compulsive Sexual Behavior Inventory. International Journal of Sexual Health, 19, 51-62.

McBride, K. R., Reece, M., \& Sanders, S. A. (2008). Using the Sexual Compulsivity Scale to predict outcomes of sexual behavior in young adults. Sexual Addiction E Compulsivity, 15, 97-115.

McCoul, M. D., \& Haslam, N. (2001). Predicting high risk sexual behavior in heterosexual and homosexual men: The roles of impulsivity and sensation seeking. Personality and Individuals Differences, 31, 1303-1310.

Morgenstern, J., Parsons, J., Muench, F., Hollander, E., Bimbi, D., \& Irwin, T. (2004, $\mathrm{M}(\mathrm{H})$. Understanding and treating compulsive sexual behavior. Paper presermed at the American Psychiatric Association Annual Conference, New York, NY.

Muench, F. Morgenstern, J., Hollander, E., Irwin, T., O'Leary, A., Parsons, J. T., ... (1) 27) The consequences of compulsive sexual behavior: The preliminary 
reliability and valid $\mathrm{f}$ the Compulsive Sexual Behavior Consequences Scale. Sexual Addiction a Compulsivity, 14, 207-220.

Parsons, J. T., Kelly, B. C., Bimbi, D. S., DiMaria, L., Wainberg, M. L., \& Morgenstern, J. (2008). Explanations for the origins of sexual compulsivity among gay and bisexual men. Archives of Sexual Behavior, 37, 817-826.

Parsons, J. T., Severino, J. P., Grov, C., Bimbi, D. S., \& Morgenstern, J. (2007). Internet use among gay and bisexual men with compulsive sexual behavior. Sexual Addiction \& Compulsivity, 14, 239-256. compulsive/impulsive traits in compulsive sexual behavior. Comprehensive Psychiatry, 44, 370-380.

Raymond, N. C., Lloyd, M. D., Miner, M. H., \& Kim, S. W. (2007). Preliminary report on the developn and validation of the Sexual Symptom Assessment Scale. Sexual Addiction d Compulsivity, 14, 119-129.

Reece, M. (2003). Sexual compulsivity and HIV serostatus disclosure among men who have sex with men. Sexual Addiction \& Compulsivity, 10, 1 (

Reece, M., \& Dodge, B. (2004). Exploring indicators of sexual compulsivity among men who cruise for sex on campus. Sexual Addiction \& Compulsivity, 11, 1-27. Reece, M., Plate, P., L., \& Daughtry, M. (2001). HIV prevention and sexual compulsivity: The need for an integrated strategy of public health and mental health. Sexual Addiction and Compulsivity, 8, 157-167.

Rolison, M. R. (2002). Factors influencing adolescents' decision to engage in risktaking behaviors. Adolescence, 37, 585-597.

Sanz, J., \& Vázquez, C. (1998). Fiabilidad, validez y datos normativos del inventario para la depresión de Beck [ENGLISH TRANSLATIOIDsicotbema, 10, 303-318. 


\section{APPENDIX I} ESCALA DE COMPULSIVIDAD SEXUAL Ballester, Gil, Ruiz, Giménez y Gómez (Traducida de Kalichman et al., 1994)

A continuación se presentan una serie de afirmaciones sobre tu comportamiento sexual. Por favor, contesta con sinceridad, tus respuestas son anónimas y confidenciales.

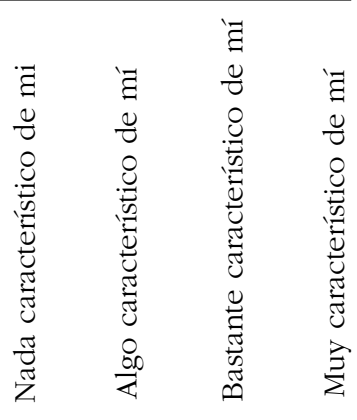

1. Mi gran apetito sexual ha sido un obstáculo en mis relaciones.

2. Mis pensamientos y comportamientos sexuales me están causando problemas en la vida.

3. Mis deseos de tener sexo han afectado a mi vida cotidiana.

4. A veces no consigo cumplir con compromisos y responsabilidades a causa de mis comportamientos sexuales.

5. A veces llego a ponerme tan caliente que podría perder el control.

6. Me sorprendo a mi mismo pensando sobre sexo en el trabajo.

7. Siento que mis pensamientos y sensaciones sexuales son más fuertes que yo.

8. Tengo que luchar para controlar mis pensamientos y comportamientos sexuales.

9. Pienso en sexo más de lo que me gustaría.

10. Me ha resultado difícil encontrar parejas sexuales que desearan tener sexo tanto como yo.

Total score: Sum of all items rated from 1 to 4 .

Subscale "Interference": Sum of items 1, 2, 3, 4 and 10.

Subscale "Failure to control sexual impulses": Sum of items 5, 6, 7, 8, 9. 